\title{
PROHIBITION OF GENDER DISCRIMINATION IN SOME INTERNATIONAL REGULATIONS
}

\author{
C. A. Ivănuṣ
}

\section{Cătălina-Adriana Ivănuș}

The Bucharest University Economic Study, Law Department, Bucharest, Romania *Correspondence: Cătălina-Adriana Ivănuș, The Bucharest University Economic Study, The Law Department, 15-17 Dorobanţi Avenue, District 1, Postal Code 71131, Bucharest, Romania, room 2506

E-mail: catalinaivanus@gmail.com

\begin{abstract}
Non-discrimination it is considered a basic and general principle relating to the protection of human rights. International human rights system aims to protect against gender discrimination in two ways: through the principles of non-discrimination and equality in treaties that do not focus specifically on the enjoyment of women rights and through a women-specific human rights treaty.
\end{abstract}

Keywords: equality fundamental rights, gender, international law

\section{Introduction}

Non-discrimination it is considered a basic and general principle relating to the protection of human rights. International human rights system aims to protect against gender discrimination in two ways: through the principles of non-discrimination and equality in treaties that do not focus specifically on the enjoyment of women rights and through a women-specific human rights treaty.

This article aims to present the main international provisions on prohibition of discrimination, especially gender discrimination.In acest articol nu se vor prezenta prevederile de la nivelul UE. This article will not present EU provisions.

\section{The definition of discrimination}

The Human Rights Committee consider that "non-discrimination, together with equality before the law and equal protection of the law without any discrimination, constitute a basic and general principle relating to the protection of human rights."

Neither the Universal Declaration of Human Rights nor the International Covenants define "discrimination". A definition of this term can only be found in conventions and declarations dealing with specific types or forms of discrimination. Article 1 of the Convention on the Elimination of All Forms of Discrimination against Women defines discrimination against women as "any distinction, exclusion or restriction made on the basis of sex which has the effect or purpose of impairing or nullifying the recognition, enjoyment or exercise by women, irrespective of their marital status, on a basis of equality of men and women, of human rights and fundamental freedoms in the political, economic, social, cultural, civil or any other field".

Article 1 of the Convention on the Elimination of All Forms of Racial Discrimination defines racial discrimination as "any distinction, exclusion, restriction or preference based on race, colour, descent or national or ethnic origin which has the purpose or effect of nullifying

\footnotetext{
${ }^{1}$ Human Rights Committee, General Comment No. 18, para. 1.
} 
or impairing the recognition, enjoyment or exercise, on the equal footing, of human rights and fundamental freedoms in the political, economic, social, cultural or any other field of public life".

The Human Rights Committee stated 'that the term 'discrimination' as used in the Covenant should be understood to imply any distinction, exclusion, restriction or preference which is based on any ground such as race, colour, sex, language, religion, political or other opinion, national or social origin, property, birth or other status, and which has the purpose or effect of nullifying or impairing the recognition, enjoyment or exercise by all persons, on an equal footing, of all rights and freedoms". ${ }^{2}$ But "the enjoyment of rights and freedoms on an equal footing does not mean identical treatment in every instance". ${ }^{3}$

The European Court of Human Rights consider article 14 is violated "when States treat differently persons in analogous situations without providing an objective and reasonable justification", it now also considers "that this is not the only facet of the prohibition of discrimination in Article 14" and that "the right not to be discriminated against in the enjoyment of the rights guaranteed under the Convention is also violated when States without objective and reasonable justification fail to treat differently persons whose situations are significantly different."

\section{Legal provisions}

2.1 Universal Declaration of Human Rights (1948), (UDHR)

The Universal Declaration of Human Rights was adopted and proclaimed by UN General Assembly Resolution 217 A (III) of 10 December 1948.

Although intended as a non-binding declaration, it is often cited in cases before both national and international tribunals. ${ }^{5}$ Some autors ${ }^{6}$ consider the Universal Declaration of Human Rights has acquired the status of universally recognized norms of customary international law that bind all Member States of the United Nations.

The preamble to the Universal Declaration of Human Rights states that "recognition of the inherent dignity and of the equal and inalienable rights of all members of the human family is the foundation of freedom, justice and peace in the world."

Provisions relevant to equality and non-discrimination are those of articles 1, 2 and 7.

Article 1 of the Universal Declaration proclaims that "all human beings are born free and equal in dignity and rights", while, according to article 2: "everyone is entitled to all the rights and freedoms set forth in this Declaration without distinction of any kind, such as race, colour, sex, language, religion, political or other opinion, national or social origin,property, birth or other status. Furthermore, no distinction shall be made on the basis of the political, jurisdictional or international status of the country or territory to which a person belongs, whether it be independent, trust, non-self-governing or under any other limitation of sovereignty."

So according to article 2 of the Declaration "distinctions of any kind" are prohibited. This could be read as meaning that no differences can be legally tolerated.

With regard to the right to equality, article 7 of the Universal Declaration stipulates that: "all are equal before the law and are entitled without any discrimination to equal protection of the law. All are entitled to equal protection against any discrimination in violation of this Declaration and against any incitement to such discrimination."

\footnotetext{
${ }^{2}$ Human Rights Committee, General Comment No. 18, para. 7.

3 Ibid., para. 8 .

${ }^{4}$ European Court of Human Rights, Case of Thlimmenos v. Greece, judgment of 6 April 2000, para. 44.

5 Kitching, K. (ed.), Non-Discrimination in International Law. A handbook for practitioners, Interights Publishing House, London, 2005, p. 28.

${ }^{6}$ Alston, P., Steiner, H. (eds.), International Human Rights in Context, Clarendon Press Publishing House, Oxford, 1996, p. 143.
} 
Article 2 and 7 applies only to the rights and freedoms set forth in Declaration. These are considered a dependent provision as it guarantees non-discrimination with respect only to the rights guaranteed by the ICCPR. ${ }^{7}$

\subsection{European Convention on Human Rights (1950), (ECHR)}

The European Convention on Human Rights was adopted by the Council of Europe in 1950 and entered into force in 1953.

Article 14 states: "the enjoyment of the rights and freedoms set forth in this Convention shall be secured without discrimination on any ground such as sex, race, colour, language, religion, political or other opinion, national or social origin, association with a national minority, property, birth or other status."

Article 1 is the central provision of the ECHR concerning equality. It can be interpreted as an open-ended prohibition of discrimination because of the use of the words "other status".

The protection it gives is dependent in that it only covers " the rights and freedoms set forth in Convention". In the case of Rasmussen v. Denmark, the European Court of Human Rights ${ }^{8}$ states that "Article 14 complements the other substantive provisions of the Convention and the Protocols. It has no independent existence since it has effect solely in relation to "the enjoyment of the rights and freedoms" safeguarded by those provisions. Although the application of Article 14 does not necessarily presuppose a breach of those provisions - and to this extent it has autonomous meaning - there can be no room for its application unless the facts at issue fall within the ambit of one or more of the latter."

According to European Court of Human Rights jurisprudence ${ }^{9}$, discrimination for the purposes of Article 14 occurs where: there is different treatment of persons in analogous or relevantly similar situations; and that difference in treatment has no "objective and reasonable justification." An objective and reasonable justification is established if the measure in question has a legitimate aim and there is "a reasonable relationship of proportionality between the means employed and the aim sought to be realized".

In Hugh Jordan v. the United Kingdom the court acknowledged that "where a general policy or measure has disproportionately prejudicial effects on a particular group, it is not excluded that this may be considered as discriminatory notwithstanding that it is not specifically aimed or directed at that group". ${ }^{10}$ In D.H. and Others v. the Czech Republic the Court expressly named a discriminatory act as indirect discrimination. Therefore, the European Convention on Human Rights provides protection to bort direct adn indirect discrimination.

In 4 November 2000 was adopted Protocol No. 12 to the European Convention, which expands the scope of the prohibition of discrimination. The Protocol contains a general prohibition of discrimination. Article 1(1) provides that "the enjoyment of any right set forth by law shall be secured without discrimination on any ground such as sex, race, colour, language, religion, political or other opinion, national or social origin, association with a national minority, property, birth or other status". Article 1(2) states that "no one shall be discriminated against by any public authority on any ground such as those mentioned in paragraph 1". The Protocol is into force but not all member states ratified it.

Some autors goes even further in stating that, "the equality right arises even if the right has not been specially granted, but inferred from a duty imposed upon a public authority. For

\footnotetext{
7 Kitching, K. (ed.), Non-Discrimination in International Law. A handbook for practitioners, Interights Publishing House, London, 2005, p. 31.

${ }^{8}$ European Court of Human Rights, Case of Rasmussen v. Denmark, judgment of 28 November1994, para. 29.

${ }^{9}$ European Court of Human Rights, Case "relating to certain aspects of the laws on the use of languages in education in Belgium" v. Belgium, judgment of 23 July 1968, para. 10.

${ }^{10}$ European Court of Human Rights, Case of Hugh Jordan v. the United Kingdom, final judgment of 4 August 2001, para. 154.
} 
example, the statutory duty to provide education for school-age children, or to house unintentional homeless, while not necessary creating rights in individuals, would attract the duty not to discriminate." 11

It is clear from the wording of this article that it is an independent provision prohibiting discrimination in the enjoyment of any right or benefit under national law.

\subsection{International Covenant on Civil and Political Rights (1966), (ICCPR)}

The UN General Assembly adopted the ICCPR in 1966, which entered into force in 1976.

The right to equality and freedom from discrimination is protected by various provisions of the International Covenant on Civil and Political Rights.

In article 2(1) each State party: "undertakes to respect and to ensure to all individuals within its territory and subject to its jurisdiction the rights recognized in the present Covenant, without distinction of any kind, such as race, colour, sex, language, religion, political or other opinion, national or social origin, property, birth or other status."

Article 26 states that "all persons are equal before the law and are entitled without any discrimination to the equal protection of the law. In this respect, the law shall prohibit any discrimination and guarantee to all persons equal and effective protection against discrimination on any ground such as race, colour, sex, language, religion, political or other opinion, national or social origin, property, birth or other status." Article 26 it is considered the cornerstone of protection against discrimination under this Covenant.

These articles does not enumerate all of the grounds of discrimination and include a general provision "or other status". ${ }^{12}$

Article 2(1) provides protection only in connection with the rights recognized in the Covenant. This is considered a dependent provision as it guarantees non-discrimination with respect only to the rights guaranteed by the ICCPR..$^{13}$ Contrary to article $2(1)$, article 26 in an autonomous right of equality and "prohibits discrimination in law or in fact in any field regulated and protected by public authorities". So the rights granted by legislation must be provided without discrimination.

Gender equality is emphasized in article 3, according to which States parties "undertake to ensure the equal right of men and women to the enjoyment of all civil and political rights set forth in the present Covenant".

Article 14 provides that "all persons shall be equal before the courts and tribunals".

Human Rights Committee states that "purpose and effect" ${ }^{14}$ of any measure must comply with the Covenant. ${ }^{15}$ This suggests that direct and indirect discrimination are prohibided. Human Rights Committee emphasis and "the principle of equality sometimes requires States parties to take affirmative action in order to diminish or eliminate conditions which cause or help to perpetuate discrimination prohibited by the Covenant". ${ }^{16}$

\section{(ICESCR)}

2.4 International Covenant on Economic, Social and Cultural Rights (1966),

The International Covenant on Economic, Social and Cultural Rights was adopted the in 1966 and entered into force in 1976.

\footnotetext{
${ }^{11}$ Sandra Fredman, Discrimination Law, Oxford University Press Publishing House, Oxford, 2001, p. 52.

12 Is an "open ended" provision.

13 Kitching, K.(ed.), Non-Discrimination in International Law. A handbook for practitioners, Interights Publishing House, London, 2005, p. 31.

${ }^{14}$ This could be interpreted as prohibiting direct discrimination ("purpose") and indirect discrimination ("effect")

${ }^{15}$ Human Rights Committee, General Comment No. 18, para. 7.

${ }^{16}$ Ibid., para. 10.
} 
Under article 2(2) the States parties undertake "to guarantee that the rights enunciated in the present Covenant will be exercised without discrimination of any kind as to race, colour, sex, language, religion, political or other opinion, national or social origin, property, birth or other status". The States also undertake under article 3 "to ensure the equal right of men and women to the enjoyment of all economic, social and cultural rights set forth in the present Covenant".

The provisions of the ICESCR (Articles 2(2) and 3) are similar to Articles 2(1) and 3 of the ICCPR and were intended in the relevant parts to have the same meaning. There is no equivalent of Article 26 in the ICESCR.

Article 2(2) it is considered a dependent provision as it guarantees "the rights enunciated in the present Covenant". This article contains a nonexhaustive list of grounds protected, so it is an "open ended" provision. CESCR states that Article 2(2) prohibits direct and indirect discrimination. ${ }^{17}$ The states are required to ensure formal and substantive equality, which means that they are permitted to take positive action and may be required to do so in order to prevent discrimination. ${ }^{18}$

Gender equality is contained in article 7(a) (i), which guarantees "fair wages and equal remuneration for work of equal value without distinction of any kind, in particular women being guaranteed conditions of work not inferior to those enjoyed by men, with equal pay for equal work".

Lastly, article 7(c) of the Covenant secures the right to "equal opportunity for everyone to be promoted in his employment to an appropriate higher level, subject to no considerations other than those of seniority and competence".

\subsection{Convention on the Elimination of All Forms of Discrimination against Women (1979), (CEDAW)}

The Convention on the Elimination of All Forms of Discrimination against Women was adopted in 1979 and entered into force in 1981.

Article 1 of the Convention defines discrimination against women as "any distinction, exclusion or restriction made on the basis of sex which has the effect or purpose of impairing or nullifying the recognition, enjoyment or exercise by women, irrespective of their marital status, on a basis of equality of men and women, of human rights and fundamental freedoms in the political, economic, social, cultural, civil or any other field".

Protection against discrimination in CEDAW is limited to discrimination against women. Article 1(1) refers to only one ground of discrimination, namely sex discrimination.

Article 1(1) autonomous right of equality and prohibits "any distinction, exclusion or restriction made on the basis of sex". This article does not enumerate all of the grounds of discrimination and include a general provision "or other field". Article 1(1) is similar to Articles 2(1) of the ICCPR and Article 2(2) of the ICESCR, thus this article could be interpreting in the same way as the other two articles in that prohibit both direct and indirect discrimination.

The achievement of equality not only de jure but also de facto demands sometimes that an affirmative action be taken by States to diminish or eliminate conditions which cause discrimination of individuals or groups of the population. Article 4(1) states that the adoption by States Parties of temporary special measures aimed at accelerating de facto equality between men and women shall not be considered as discriminatory.

Eleanor Roosevelt pointed out specialisation of certain issues or rights may lead to marginalisation and stigmatisation of women. But proponents of the this approach argue that

\footnotetext{
${ }^{17}$ Committe on Economic, Social and Cultural Rights, General comment no. 20, para. 10.

18 Kitching, K.(ed.), Non-Discrimination in International Law. A handbook for practitioners, Interights Publishing House, London, 2011, p. 29.
} 
the risk of addressing women's rights only in a mainstream human rights framework may result in these matters being completely ignored or overlooked. ${ }^{19}$

The adoption of the CEDAW meant that women's rights were expressly placed in the ambit of international human rights, but the rights of women were still ignored by the mainstream human rights mechanisms. One problem after CEDAW is that the monitoring bodies of the other human rights treaties do not solve violations of women's rights and leave these issues up to the specialised CEDAW Committee to deal with and the adoption of the CEDAW has therefore led to the marginalisation of human rights of women. So the criticism is that the mainstream human rights instruments do not pay attention to women's rights. ${ }^{20}$

\section{Conclusions}

Much has been achieved in the past six decades to prohibit and eliminate gender discrimination.

Discrimination is a dependent provision and the prohibition is linked to the enjoyment of another rights. In discrimination cases no claim can be made only in conjunction with one of the specified rights. This limitation is softened by the fact that there is not necessary to show a breach of one of the substantive rights. In other words, claims brought to justice must relate to discrimination in the enjoyment of another right, and discrimination cannot be invoked on its own, only "in conjunction with" substantive rights and there does not need to be a violation of the substantive right itself for discrimination rules to be applicable. This provision differs from the other human right.

International regulation are applicable men and women without discrimination, but the exclusions specific to are neither recognised nor protected by mainstream human rights instruments.

\section{Bibliography}

Universal Declaration of Human Rights

European Convention on Human Rights

International Covenant on Civil and Political Rights

International Covenant on Economic, Social and Cultural Rights

Convention on the Elimination of All Forms of Discrimination against Women

Convention on the Elimination of All Forms of Racial Discrimination

Committe on Economic, Social and Cultural Rights, General comment no. 20

Human Rights Committee, General Comment No. 18

European Court of Human Rights, Case of Hugh Jordan v. the United Kingdom,final judgment of 4 August 2001

European Court of Human Rights, Case of Thlimmenos v. Greece, judgment of 6 April 2000

European Court of Human Rights, Case of Rasmussen v. Denmark, judgment of 28 November 1994

European Court of Human Rights, Case "relating to certain aspects of the laws on the use of languages in education in Belgium" v. Belgium, judgment of 23 July 1968

Fleur van Leeuwen, Women's Rights Are Human Rights: The Practice of the United Nations Human Rights, "Intersentia" Publishing House, Cambridge, 2009

Hilary Charlesworth, Not Waving but Drowning: Gender Mainstreaming and Human Rights in the United Nations, Harvard Human Rights Journal, vol. 18, 2005, no.1

Kitching, K. (ed.), Non-Discrimination in International Law. A handbook for practitioners, "Interights" Publishing House, London, 2005

\footnotetext{
${ }^{19}$ Hilary Charlesworth., Not Waving but Drowning: Gender Mainstreaming and Human Rights in the United Nations, Harvard Human Rights Journal, vol. 18, 2005, no.1, p. 1.

${ }^{20}$ Fleur van Leeuwen, Women's Rights Are Human Rights: The Practice of the United Nations Human Rights, Intersentia Publishing House, 2009, pp. 8-9.
} 
C. A. Ivănuş

Sandra Fredman, Discrimination Law, "Oxford University Press" Publishing House, Oxford, 2001 .

Alston, P., Steiner H., (eds.), International Human Rights in Context, "Clarendon Press" Publishing House, Oxford, 1996. 